\title{
SELECTION OF TANNASE-PRODUCING ASPERGILLUS NIGER STRAINS
}

\author{
Gustavo A.S. Pinto ${ }^{1}$; Selma G.F. Leite ${ }^{2}$; Selma C. Terzi ${ }^{1}$; Sonia Couri ${ }^{1 *}$ \\ ${ }^{1}$ EMBRAPA/Agroindústria de Alimentos, Rio de Janeiro, RJ, Brasil. ${ }^{2}$ Departamento de Engenharia Bioquímica, \\ Escola de Química, Universidade Federal do Rio de Janeiro, Rio de Janeiro, RJ, Brasil. \\ Submitted: July 05, 2000; Returned to authors for corrections: September 14, 2000; Approved: March 03, 2001
}

\section{SHORT COMMUNICATION}

\begin{abstract}
The aim of this work was to select strains of Aspergillus niger for tannase production. Growth of colonies in plates with tannic acid-containing medium indicated their ability to synthesize tannase. Tannase activity was also measured in solid-state fermentation. A. niger 11T25A5 was the best tannase producer $\left(67.5 \mathrm{U.g}^{-1} / 72\right.$ hours of fermentation).
\end{abstract}

Key words: tannase, Aspergillus niger, screening solid-state fermentation

Tannase (tannin-acyl-hydrolase, E.C. 3.1.1.20) catalyzes the hydrolysis of ester and depside bonds in hydrolysable tannins, as tannic acid, releasing glucose and gallic acid. Bacteria (9), yeast (1) and filamentous fungi $(2,5,11)$ are known tannase producers. Species of Aspergilli were reported as the best tannase producers in submerged and solid state fermentations (4). Tannase is used in the manufacture of instant tea and production of gallic acid, a substrate for chemical synthesis of propyl gallate and trimethoprim which have applications in the food and pharmaceutical industries. Other potential uses of tannase are stabilization of malt polyphenols, clarification of beer and fruit juices (6), prevention of phenol-induced madeirization in wine and fruit juices (3) and reduction of antinutritional effects of tannins in animal feed.

The world market of fruit juice is around US\$ 5 billion/ year. Brazil has $33 \%$ of this market (7) with good growing perspectives. Cashew apple juice is a vitamin $\mathrm{C}$ rich by-product of cashew production. Sale of this juice in the world is hampered by its astringency and instability caused by the presence of phenolic compounds like tannins. Based on the potential use of tannase to reduce tannin levels in fruit juices, the aim of this work was to select Aspergillus niger strains with tannase synthesis ability.

Thirty Aspergillus niger strains from EMBRAPA/Food Technology stock collection were screened for their potential in tannase synthesis. From these, 17 were wild-type and 13 were previously isolated mutants (8). Conidia were conserved in sterile soil at $-18^{\circ} \mathrm{C}$, according to Martin (12).

Screening was performed in plates of selection medium which contained (g/L): tannic acid, 10.0, $\mathrm{NaNO}_{3}, 3.0 ; \mathrm{KH}_{2} \mathrm{PO}_{4}$, $1.0 ; \mathrm{MgSO}_{4}$. $7 \mathrm{H}_{2} 0,0.5 ; \mathrm{KCI} 0.5 ; \mathrm{FeSO}_{4} .7 \mathrm{H}_{2} \mathrm{O}, 0.01$; agar, 30.0, $\mathrm{pH}$ 4.5. Point inoculations were carried out and plates were incubated at $32^{\circ} \mathrm{C}$ for 72 hours. The diameters of the colonies were measured in 24 hours periods (8). Each strain was plated four times.

Strains selected in the first step were tested for tannase production in solid-state fermentation (SSF), carried out in conical flasks $(125 \mathrm{~mL})$ containing $10 \mathrm{~g}$ of medium (wheat bran enriched with $0.8 \% \mathrm{w} / \mathrm{w}$ tannic acid and moistened with a $0.91 \% \mathrm{w} / \mathrm{v}$ $\left(\mathrm{NH}_{4}\right)_{2} \mathrm{SO}_{4}$ solution). Flasks were sterilized $\left(121^{\circ} \mathrm{C} / 15\right.$ minutes $)$, inoculated with $0.5 \mathrm{~mL}$ of conidia suspension $\left(10^{7}\right.$ conidia $\left./ \mathrm{mL}\right)$ and incubated at $32^{\circ} \mathrm{C}$.

The enzymatic solution was obtained from the fermented medium by the addition of $25 \mathrm{~mL} 100 \mathrm{mM}$ acetate buffer $\mathrm{pH} 5.0$ per $10 \mathrm{~g}$ of fermented medium, incubated for 1 hour at $32^{\circ} \mathrm{C}$ and filtered through Whatman n.1 paper. Tannase activity was determined in the extract following Sanderson and Coggon's method (13). The average results were submitted to the Student's "t" test $(\mathrm{p}<0.05)$.

\footnotetext{
* Corresponding author. Mailing address: EMBRAPA/Agroindústria de Alimentos, CEP: 23020-470, Rio de Janeiro, RJ, Brasil. Fax: (+5521) 410-1090. E-mail: scoury@ctaa.embrapa.br
} 
In a similar screening experiment, Bradoo et al. (5) reported formation of a clear zone around the mycelium, suggesting tannase activity. However, the observation of this clear zone was very difficult. After 48 hours of incubation, Aspergillus niger, A. awamori and A. japonicus, presented diameters between 14 and $16 \mathrm{~mm}$. Yamada et al. (15) tested eighty strains of filamentous fungi for tannase production, and selected two colonies, identified as Aspergillus oryzae, which presented diameters of 20-22 mm after 72 hours. Direct measurement of the colony diameter was a good indicator of the ability of tannic acid utilization as a carbon source due to the tannase activity in the medium.

Fig. 1 shows the growth of strains in the selective medium. Some of them presented good growth and formed colonies with more than $30 \mathrm{~mm}$ of diameter in 48 hours and $40 \mathrm{~mm}$ in 72
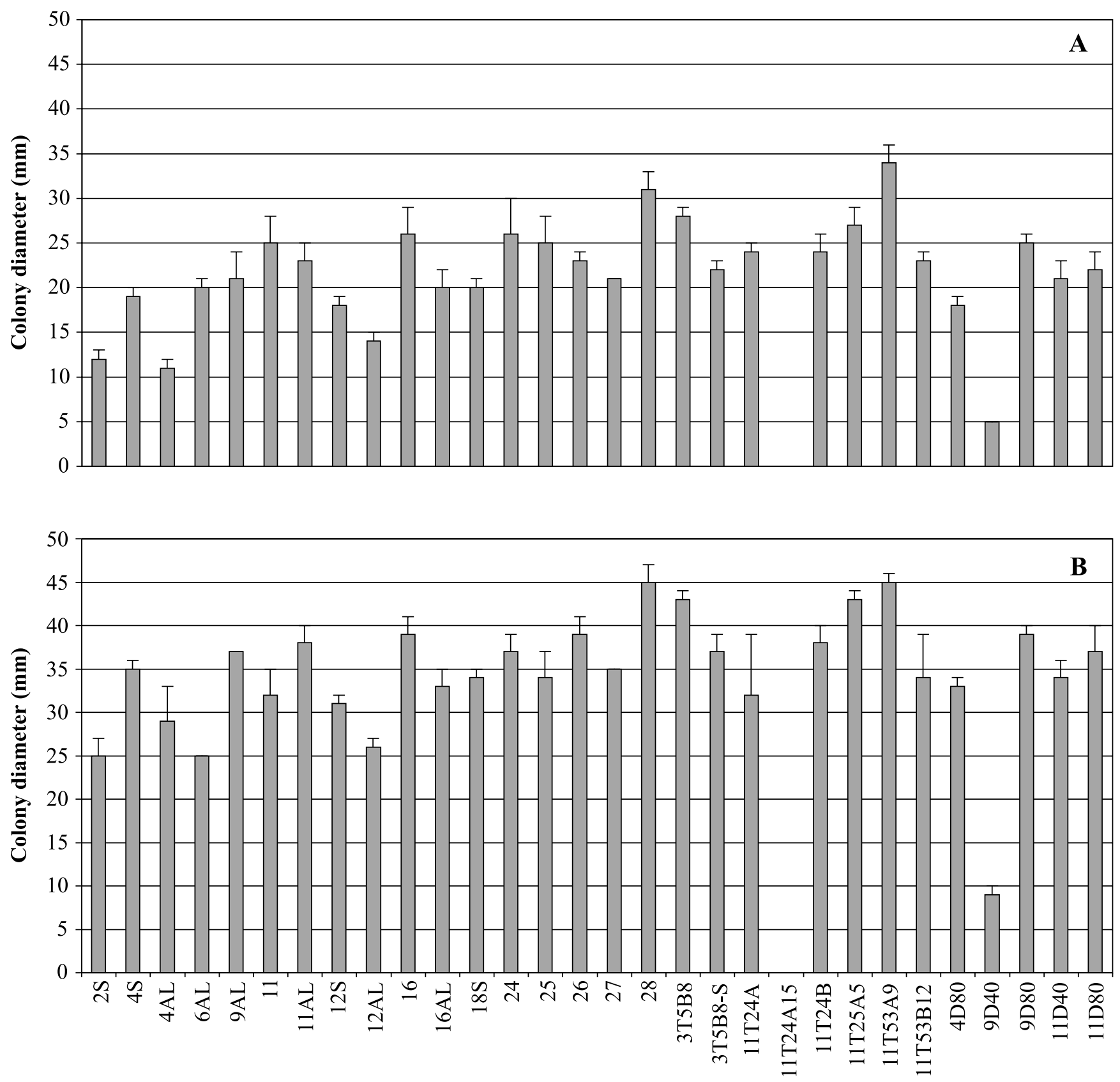

Figure 1. Colony diameters (averages of four experiments with standard deviation bars) of thirty Aspergillus niger strains in plates containing tannic acid, after 48 hours (A) and 72 hours (B) of incubation. 
Table 1. Tannase activity $\left(\mathrm{U} \cdot \mathrm{g}^{-1}\right)$ and productivity $\left(\mathrm{U}_{\mathrm{g}} \mathrm{g}^{-1} \cdot \mathrm{h}^{-1}\right)$ of four Aspergillus niger strains in solid state fermentation.

\begin{tabular}{ccccccccc}
\hline \multirow{2}{*}{ Time $(\mathrm{h})$} & \multicolumn{3}{c}{ Tannase Yield $\left(\mathrm{U} . \mathrm{g}^{-1}\right)$} & \multicolumn{4}{c}{ Productivity $\left(\mathrm{U} \cdot \mathrm{g}^{-1} \cdot \mathrm{h}^{-1}\right)$} \\
\cline { 2 - 9 } & 28 & 3T5B8 & $11 \mathrm{~T} 25 \mathrm{~A} 5$ & $11 \mathrm{~T} 53 \mathrm{~A} 9$ & 28 & 3T5B8 & $11 \mathrm{~T} 25 \mathrm{~A} 5$ & $11 \mathrm{~T} 53 \mathrm{~A} 9$ \\
\hline 24 & 0 & 40 & 0 & 45.5 & 0 & 1.67 & 0 & 1.90 \\
48 & 23.5 & 46.8 & 20.8 & 55.5 & 0.49 & 0.98 & 0.43 & 1.16 \\
72 & 26.3 & 42.8 & 67.5 & 49.5 & 0.37 & 0.59 & 0.94 & 0.69 \\
\hline
\end{tabular}

hours. A. niger 11T24A15 was the only strain which did not grow in the selective medium, indicating lack of capacity of utilization of tannic acid.

The plate method is a qualitative, simple and rapid screening procedure for tannase production. For the quantitative investigation, the wild A. niger 28 and the 3T588, 11T25A5 and 11T53A9 mutant strains, which presented colonies with more than $42 \mathrm{~mm}$ diameter after $72 \mathrm{~h}$, were selected, and assayed for enzymatic activity by Solid State Fermentation (SSF). SSF was selected because Lekha and Lonsane (10) showed that production of tannase was increased 4.8 and 2.5 times in SSF when compared to liquid surface and submerged fermentations, respectively. These authors observed that during the fermentation period A. niger PKL104, in SSF, produced intracellular tannase exclusively while in liquid fermentation, this enzyme was exclusively intracellular in the first 48 hours.

The profile of tannase production by the selected strains in SSF is shown in Table 1. All strains produced the enzyme. However, after 24 hours of fermentation, the strains A. niger 28 and 11T25A5 did not present tannase activity in the enzymatic solution. The highest tannase activity was obtained between 48 hours (for strains 3T5B8 and 11T53A9) and 72 hours (for strains 28 and 11T25A5), in accordance with the observations of Lekha and Lonsane (10). A. niger 11T25A5 was the best tannase producer, with $67.5 \mathrm{U}^{-1}{ }^{-1}$ after 72 hours. However, the maximum productivity, $1.9 \mathrm{U} \cdot \mathrm{g}^{-1} \cdot \mathrm{h}^{-1}$, was reached after 24 hours by A. niger 11T53A9. Strain 3T5B8 also demonstrated to be a good tannase producer. Among all strains tested, A. niger 28 was the poorest producer of the enzyme.

\section{ACKNOWLEDGEMENTS}

This work was supported by Conselho Nacional de Desenvolvimento Científico e Tecnológico (CNPq), Brazil.

\section{RESUMO}

\section{Seleção de linhagens de Aspergillus niger produtoras de tanase}

O objetivo deste trabalho foi selecionar linhagens de Aspergillus niger para síntese de tanase. $\mathrm{O}$ crescimento das colônias em meio contendo ácido tânico indicou capacidade de produção de tanase. A atividade enzimática foi determinada em fermentação semi-sólida. A. niger 11T25A5 foi o melhor produtor (67.5 $\mathrm{U.g}^{-1} / 72$ horas de fermentação).

Palavras-chave: tanase, Aspergillus niger, seleção, fermentação semi-solida

\section{REFERENCES}

1. Aoki, K.; Shinke, R.; Nishira H. Purification and some properties of yeast tannase. Agr. Biol. Chem., 40 (1): 79-85, 1976.

2. Bajpai, B.; Patil, S. Tannin acyl hydrolase (EC 3.1.1.20) activity of Aspergillus, Penicilium, Fusarium and Trichoderma. World J. Microbiol. Biotechnol., 12: 217-220, 1996.

3. Bajpai, B.; Patil, S. Induction of tannin acyl hydrolase (EC 3.1.1.20) activity in some members of fungi imperfect. Enzyme Microb. Technol., 20: 612614, 1997.

4. Bhat, T.K.; Singh, B.; Sharma, O.P. Microbial degradation of tannins - a current perspective. Biodegradation., 9: 343-357, 1998.

5. Bradoo, S.; Gupta, R.; Saxena, R.K. Screening of extracellular tannase producing fungi: development of a rapid and simple plate assay. J. Gen. Appl. Microbiol. 42: 325-329, 1996.

6. Cantarelli, C.; Brenna, O.; Giovanelli, G.; Rossi, M. Beverage stabilization through enzymic removal phenolics. Food Biotech., 3: 203213, 1996

7. Carraro, A.F.; Cunha, M.M. Manual de exportação de frutas. FRUPEX: Programa de apoio à produção e exportação de frutas, hortaliças, flores e plantas ornamentais. Brasília: Instituto Interamericano de Cooperação para a Agricultura, Ministério da Agricultura, do Abastecimento e da Reforma Agrária, Secretaria de Desenvolvimento Rural, 1994.

8. Couri, S.; Farias, A.X. Genetic manipulation of Aspergillus niger for increased synthesis of pectinolytic enzymes. Rev. Microbiol. 26 (4): 314317, 1995.

9. Deschamps, A.M.; Otuk, G.; Lebeualt, J.M. Production of tannase and degradation of chestnut tannin by bacteria. J. Ferment. Technol., 61: 5559, 1983

10. Lekha, P.K.; Lonsane, B.K. Comparative titres, location and properties of tannin acyl hydrolase produced by Aspergillus niger PKL 104 in solidstate, liquid surface and submerged fermentations. Process Biochem., 29 (6): 497-503, 1994.

11. Lekha, P.K.; Lomane, B.K. Production and application of tannin acyl hydrolase: state of art. Adv. Appl. Microbiol., 44: 215-260, 1997.

12. Martin, S.M. Conservation of microorganism. Ann. Rev. Microbiol., 18: 1$16,1964$.

13. Sanderson, G.W.; Coggon, P. Green tea conversion using tannase and natural tea enzyme. U.S. Patent 3,812,266. 1974.

14. Viglio, E.B.C.L. Indústria de alimentos - caracterização e tendências para o ano 2000. Agroanalysis. 16 (9): 6-12, 1996.

15. Yamada, K.; Iibuchi, S.; Minoda, Y. Studies on tannin acyl hydrolase of microorganisms. Hakko Kogaku Zasshi, 45 (3): 233-240, 1967. 